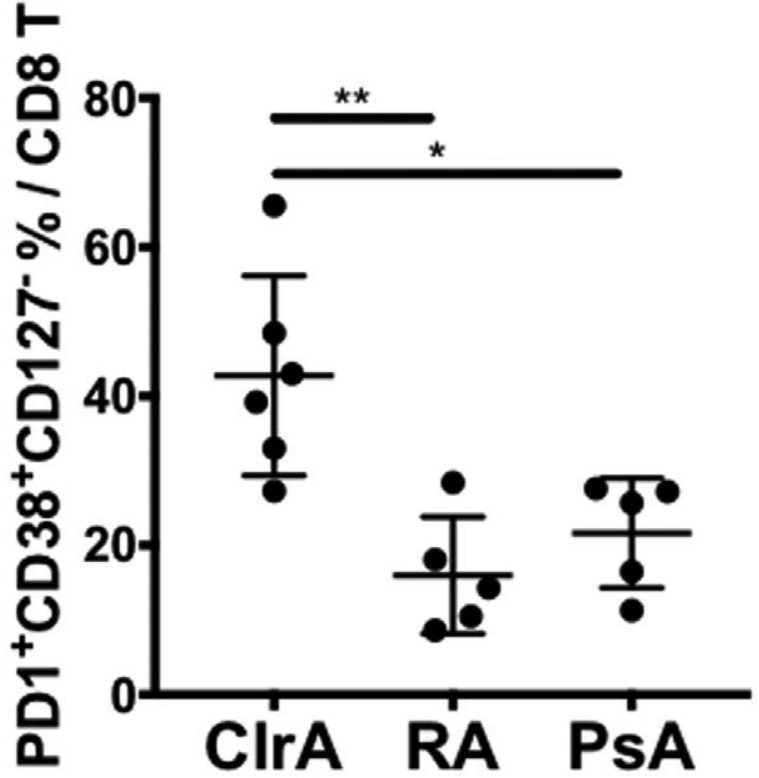

Figure 2. Synovial fluid PD $-1^{+} \mathrm{CD} 38^{\text {hi }} \mathrm{CD} 127^{-} \mathrm{CD} 8^{+} \mathrm{T}$ cells

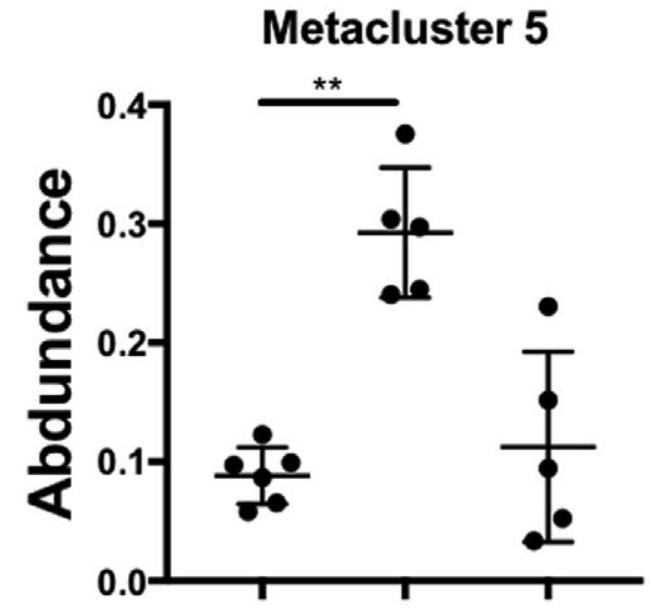

Figure 3. Synovial fluid $\mathrm{CD} 4^{+} \mathrm{T}$ peripheral helper cells

Disclosure of Interests: Runci Wang: None declared, Karmela Kim Chan: None declared, Amy Cunningham-Bussel: None declared, Laura Donlin Consultant of: Consultant - Genentech/Roche, Gregory Vitone: None declared, Aidan Tirpack: None declared, Caroline Benson: None declared, Gregory Keras: None declared, A. Helena Jonsson: None declared, Michael Brenner: None declared, Anne Bass: None declared, Deepak Rao Grant/research support from: Has received research grant support from Celgene and Merck., Consultant of: Has received consulting fees or honoraria from Merck, Pfizer, GlaxoSmithKine, Bristol-Myers Squibb, Janssen, and Scipher Medicine DOI: 10.1136/annrheumdis-2020-eular.1075

\section{OP0329-PARE IN SHORT: EASY-TO-UNDERSTAND INFORMATION FOR VULNERABLE GROUPS}

\section{Krafft ${ }^{1}$, E. Rösch ${ }^{1} .{ }^{1}$ Rheumaliga Schweiz, Zürich, Switzerland}

Background: Some 800,000 people in Switzerland have trouble reading (1). For people with reading or learning difficulties, many texts are too complex or simply too long. People with a migrant background likewise often lack access to health information, in their case due to language barriers.

Objectives: One of the top priorities set out in Switzerland's "National Strategy on Musculoskeletal Diseases (2017-2022) is to develop low-threshold services for vulnerable groups. In keeping with this strategy, the Swiss League against Rheumatism (SLR) wants to reach out to people with a migrant background as well as those with reading difficulties by making available to them helpful and readily understandable information material on rheumatic diseases.

Methods: During the planning phase, the SLR collaborated with migesplus, the portal for equal health opportunities operated by the Swiss Red Cross. Their input flowed into the conception of the new publication series "kurz \& knapp" (in short).

The texts for the new series are written in accordance with the rules for Easy Language, with the help of an expert committee from Pro Infirmis, the Swiss professional organisation for people with disabilities (www.buero-leichte-sprache ch). After being evaluated, the final texts then receive a seal of approval. Easy Language is a key component of accessibility, because it makes complex content accessible to a wider audience.

For the benefit of people with a migrant background, the SLR has the texts translated not only into the three Swiss national languages German, French and Italian but also into Albanian, Bosnian/Croatian/Montenegrin/Serbian, Portuguese Spanish and Turkish.

Brochures on "Gout" and "Arthrosis" have already been published in the "kurz \& knapp" series. In 2020, a publication on the subject of "Back Pain" will follow. In order to make the publications known to the intended target groups, the SLR wrote to various multipliers, such as immigration offices and foreign media.

The publications are available free of charge in the online shop.

Results: The new series "kurz \& knapp" has been commended in particular by migration experts. Within the last ten months, the SLR has already distributed over 1,000 copies.

Conclusion: To reach people with reading difficulties or a migrant background - groups that make up a large part of the Swiss population - specially designed communication tools are needed. An interdisciplinary network is indispensable for the development and dissemination of such tools.

References:

[1] Notter, P. \& Arnold, C (2006). Lesen und Rechnen im Alltag: Grundkompetenzen von Erwachsenen in der Schweiz. Swiss Federal Statistical Office (BFS). Accessed on 28 January 2020: https://www.lesen-schreiben-schweiz. ch/myUploadData/files/ALL-StudieD.pdf

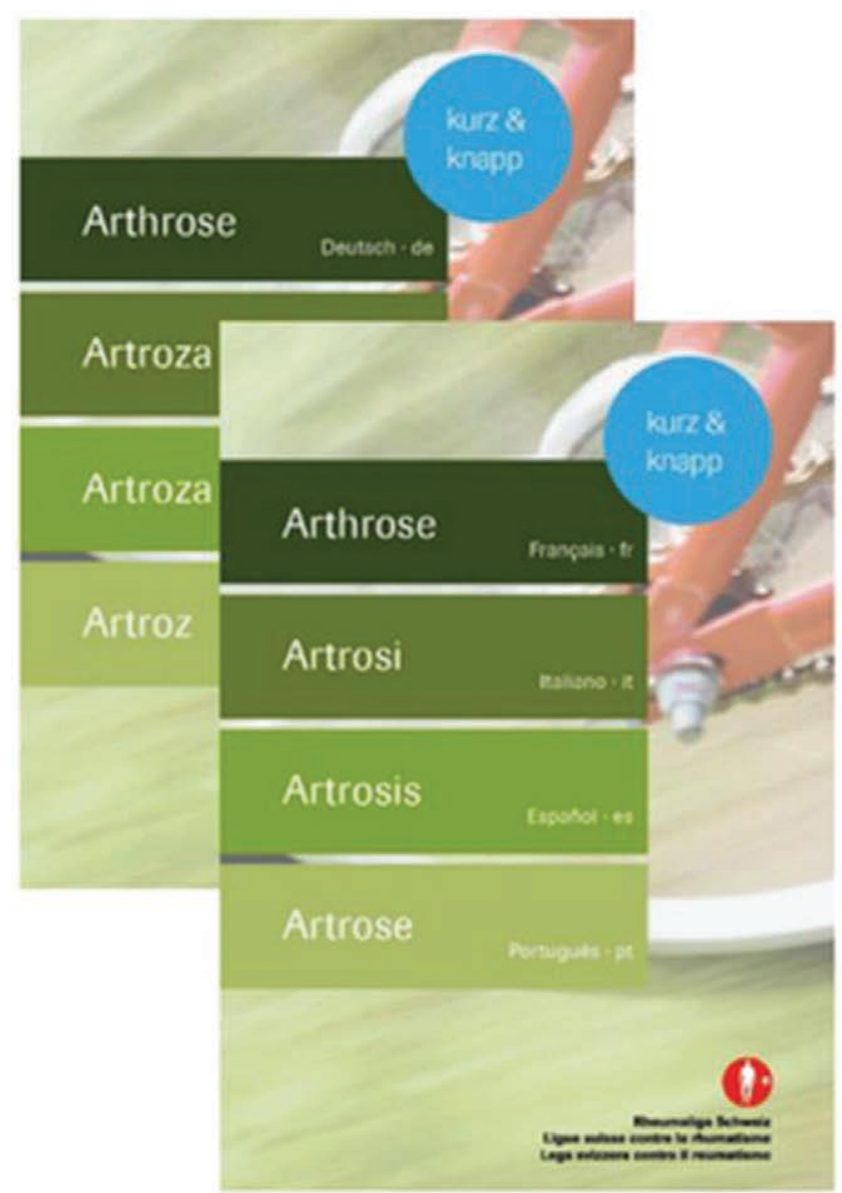

Disclosure of Interests: Valérie Krafft Grant/research support from: Yes, Menarini AG (for gout brochure), Eva Rösch: None declared DOI: 10.1136/annrheumdis-2020-eular.4240 